\title{
領域気象モデル WRF による多治見高温化要因の感度解析 A SENSITIVITY ANALYSIS OF THE FACTORS IN HIGH TEMPERATURES IN TAJIMI BY USING WRF
}

\author{
伊 藤 奨*, 飯 塚 悟**, 黒木 美早衣*** \\ Susumu ITO, Satoru IIZUKA and Misae KUROKI
}

\begin{abstract}
Tajimi, a city located in Gifu Prefecture, experienced the record high temperature in Japan $\left(40.9^{\circ} \mathrm{C}\right)$ on August 16, 2007. The problems associated with high temperatures in summer are very serious in the city. It is considered that various factors such as topographic basin effect and heat island around Nagoya affect high temperatures in Tajimi. However, each contribution of those factors is not clear enough. In this study, a sensitivity analysis of the factors in high temperatures in Tajimi for recent five years was conducted by using a regional atmospheric model, WRF (Weather Research and Forecasting). Here, we investigated the effects of urban heat islands in Tajimi and Nagoya and topographical effects on the thermal environment in Tajimi.
\end{abstract}

Keywords : High Temperatures in Tajimi, Thermal Environment, Sensitivity Analysis, WRF 多治見高温化，温熱環境，感度解析，WRF

1. 序

2010 年の夏は日本各地において記録的な猛暑となったが、近年、 猛暑の増加が健康被害（熱中症、睡眠障害など）や冷房エネルギー 消費に大きな影響を及ぼし、深刻な問題となっている。2007 年 8 月 16 日に国内観測史上最高気温となる $40.9^{\circ} \mathrm{C}$ を記録した岐阜県多治 見市は、猛暑が特に顕著な都市である。その出現頻度は名古屋や東 京のような大都市よりも高い。猛暑日（日最高気温 $35^{\circ} \mathrm{C}$ 以上）の平 年值（1981 年〜2010 年の 30 年間の平均值）は、名古屋が 6.6 日、 東京が 1.7 日であるのに対し、多治見は 11.9 日となっている（表 1 参照） 1)。また、多治見では日最高気温が $38^{\circ} \mathrm{C}$ 以上となるような著 しい高温の発生頻度も高くなっている ${ }^{2)}$ 。図 1 は、多治見のアメダ 又観測所における 1981 年〜2010 年の 8 月 1 力月間の猛暑日数と日 中午後平均気温（8月 1 ケ月 13 時〜 18 時の平均值）の経年変化を示 したものである ${ }^{1)}$ 。1994 年以降に猛暑日の発生頻度と日中午後平均 気温が高くなり、多治見の高温化が顕在化している様子が見られる。

多治見の高温化（本研究では特に、日中午後において多治見市街 地が周辺に比べて高温となる状況を「多治見高温化」と呼ぶことに する) は幾つかの要因が重なって形成されていると考えられている。 内陸に位置する多治見は周辺が山岳に囲まれた盆地地形であるため、 日中に熱が滞留し気温が高くなりやすい。また、山岳を越えて吹き 降ろす気流が昇温をもたらすフェーン現象も高温化の一因として指 摘されている。さらに、多治見自体の都市化に伴うヒートアイラン ドや、隣接する大都市名古屋のヒートアイランドの影響(熱の移流) も高温化の要因として考えられている。しかし、多治見高温化の形 成メカニズムや要因解明に関寸る研究は少なく、多治見高温化に対 する各種要因の寄与度については未だ十分に明確ではない。
表 1 各都市における猛暑·熱帯夜日数の平年値(1981 年～2010 年)

\begin{tabular}{|c|c|c|}
\hline & 猛暑日数 & 熱帯夜日数 \\
\hline \hline 多治見 & 11.9 & 2.0 \\
\hline 名古屋 & 6.6 & 11.6 \\
\hline 東京 & 1.7 & 15.1 \\
\hline 大阪 & 7.9 & 19.8 \\
\hline
\end{tabular}

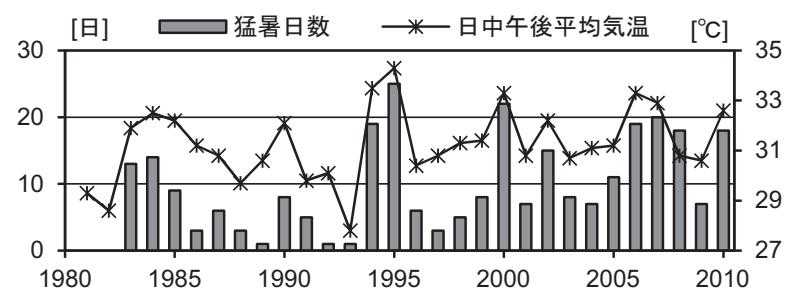

図 1 多治見における猛暑日数・日中午後平均気温の経年変化

夏季の暑熱環境の解析において、数值モデル（数值シミュレーシ ヨン）の適用は有効な手段の 1 つである。渡来ら ${ }^{3)}$ 、篠原ら ${ }^{4)}$ 、 Takane ら ${ }^{5)}$ は、数值モデルにより 2007 年 8 月中旬の関東地方の猛暑・高温 化 $(2007$ 年 8 月 16 日に熊谷において多治見と同じ国内最高気温 $40.9^{\circ} \mathrm{C}$ を記録）の解析を行っている。これらの研究では、関東の高 温化に関して、晴天日が続いたことによる地表面の日射加熱の影響 や、高気圧に覆われ、大規模な下降流場で断熱圧縮による昇温（鉛 直方向の熱の拡散の抑制も含む) の影響が大きいことが示されてい る。その他の要因として、領域気象モデル WRF (Weather Research and Forecasting） ${ }^{6-8)}$ を用いて解析した渡来ら ${ }^{3)}$ 、気象庁非静力学モデル JMANHM を用いて解析した篠原ら ${ }^{4}$ は、降水を伴わない力学的フ
* 名古屋大学大学院環境学研究科 大学院生

** 名古屋大学大学院環境学研究科 准教授 $\cdot$ 博士 (工学)

*** 東邦ガス(株) 修士 (工学)
Graduate Student, Graduate School of Environmental Studies, Nagoya University Assoc. Prof., Graduate School of Environmental Studies, Nagoya University, Dr. Eng. Toho Gas Co., Ltd., M. Eng. 
ェーン（乾いたフェーン）の影響も示唆している。WRF を用いて解 析を行った Takane ら ${ }^{5)}$ は、山岳斜面を下降する際に地表面からの加 熱により暖められた山越え気流（foehnlike wind）の影響についても 指摘している。多治見の猛暑・高温化に関しては、小出ら ${ }^{9)}$ が JMANHM を用いて 2007 年 8 月 16 日の再現実験を行い、地表付近 の風系に加えて多治見の盆地地形の影響を指摘している。以上のよ うに、近年、高温化に関する数值モデル研究が精力的に行われてき ているが、研究事例は未だ少なく、高温化解明のための知見は十分 とは言えない。高温化の形成メカニズムの十分な理解をなくしては、 真に有効な緩和策を策定寸ることは困難であると考える。

そこで本研究では、領域気象モデル $\mathrm{WRF}^{(6)-8)}$ を用いた感度解析に より、多治見高温化の形成要因について検討寸る。夏季の暑熱環境 の評価においては、不確実性の高い短期解析（特定日の解析など） だけでは不十分で、ある程度長期間の解析が必要と考えられる注 1)。 ここでは、2006 年〜2010 年の 5 年間それぞれの 8 月 1 ケ月間を対象 とし、長期的な解析に基づいて多治見高温化の形成要因の評価を行 うこととする。本研究ではまず、2006 年〜2010 年それぞれの 8 月 1 ケ月間の現状再現シミュレーションを行い、アメダス観測データと の比較から、WRF の予測精度を検証寸る。次に、多治見高温化の形 成要因として考えられているもののうち、(1)多治見自体の都市化(七 ートアイランド）の影響、(2)名古屋の都市化（ヒートアイランド） の影響、(3)周辺地理状況の影響（琵琶湖からの湖風の影響） 注 2)、の 3つの地理的要因に着目し、それらの要因の感度解析を行う。

\section{2. シミュレーションの概要}

\section{1 シミュレーションモデル}

完全圧縮・非静力学の領域気象モデル WRF (version 3.0.1.1 の ARW (Advanced Research WRF) ) を使用した。WRF はアメリカ・国立大 気研究センターNCAR（National Center for Atmospheric Research）を 始めとするアメリカの数々の気象研究機関が共同で開発を進めてき た世界最新鋭の領域気象モデルである。WRF は従来の気象モデルに 比べて予測精度に優れ、その適用可能範囲は数 $100 \mathrm{~m}$ 程度の空間ス ケールから全球スケールに及んでいる。筆者らは近年、都市温熱環 境の将来予測の研究 ${ }^{10), 11}$ にも WRF を利用している。

\section{2 解析領域}

図 2 と表 2 に示す 3 段階のネスティングを施した領域を解析した。 第 1 領域は日本全域、第 2 領域は中部地方全域が含まれるように設 定している。第 3 領域が主となる解析領域で、多治見市や名古屋市 を含む水平 $120 \mathrm{~km} \times 120 \mathrm{~km}$ の範囲である (水平格子解像度は $1 \mathrm{~km}$ )。 なお、ネスティングは全て 1 方向ネスティングとした。

\section{3 解析期間}

2006 年〜2010 年の 5 年間それぞれの 8 月 1 ケ月間を解析した。全 ての年において、助走計算を含めるため、7 月 30 日午前 9 時から積 分を開始している。

\section{4 解析ケース}

多治見高温化の形成要因としては、晴天日が続くことによる地表 面の日射加熱などの気象要因も考えられるが、気象要因の感度解析 のための適切な条件設定は困難（例えば、広域の大局的な気象現象 (背景場) が存在する中で、多治見周辺のみで晴天日の日数をコン トロール寸ることは困難）であることもあり、本研究では、(1)多治

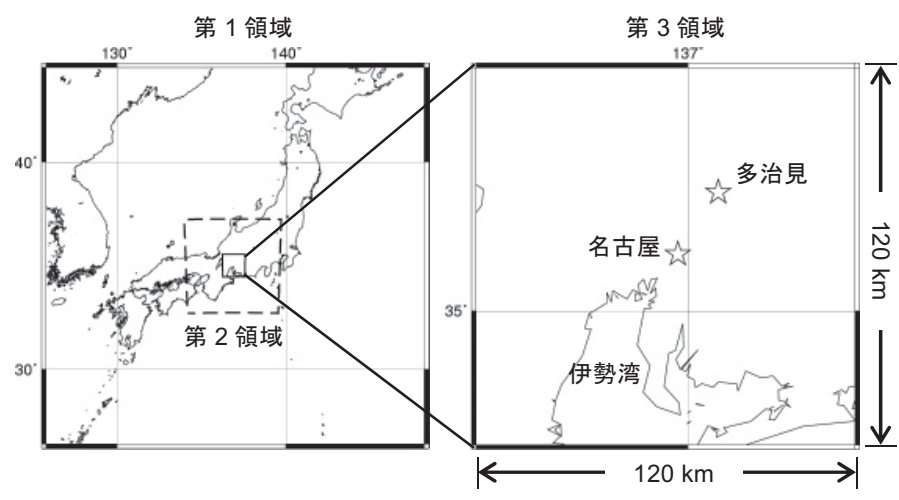

図 2 解析領域

表 2 解析領域の大きさと格子数・格子間隔

\begin{tabular}{|c|c|c|c|}
\hline 領域 & 大きさ $x \times y \times z$ & 格子数 $x \times y \times z$ & 水平格子間隔 \\
\hline \hline 第 1 領域 & $1975 \mathrm{~km} \times 1975 \mathrm{~km} \times 21 \mathrm{~km}$ & $79 \times 79 \times 34$ & $25 \mathrm{~km}$ \\
\hline 第 2 領域 & $500 \mathrm{~km} \times 500 \mathrm{~km} \times 21 \mathrm{~km}$ & $100 \times 100 \times 34$ & $5 \mathrm{~km}$ \\
\hline 第3 領域 & $120 \mathrm{~km} \times 120 \mathrm{~km} \times 21 \mathrm{~km}$ & $120 \times 120 \times 34$ & $1 \mathrm{~km}$ \\
\hline
\end{tabular}

表 3 解析ケース

\begin{tabular}{|c|c|c|c|}
\hline ケース & 変更領域 & 変更項目 & 評価する影響 \\
\hline \hline Case 0 & \multicolumn{3}{|c|}{ 現状再現 } \\
\hline Case 1 & 多治見市域 & 「都市」の約半分 $\rightarrow$ 「草原」 & 多治見の都市化 \\
\hline Case 2 & 名古屋市域 & 全ての「都市」 $\rightarrow$ 「草原」 & 名古屋の都市化 \\
\hline Case 3 & 琵琶湖 & 全ての「水域」 $\rightarrow$ 「草原」 & 湖風 \\
\hline
\end{tabular}

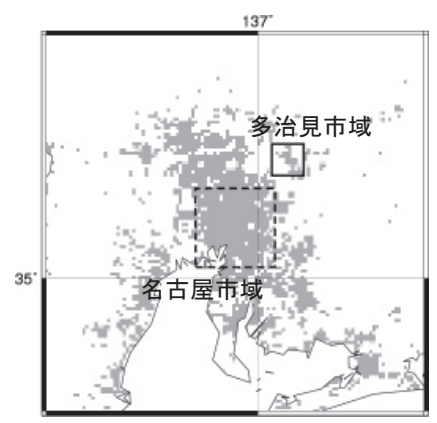

図 3 第 3 領域の「都市」区分域（死色部分）

見自体の都市化（ヒートアイランド）の影響、(2)名古屋の都市化（ヒ ートアイランド）の影響、(3)琵琶湖からの湖風の影響注 2)、の 3 つの 地理的要因に着目し、表 3 に示寸 4 つのケースを設定した。

Case 0 は現状再現を目的としたケースである。Case 1〜Case 3 は Case 0 に対し、上記(1)〜(3)の条件を変化させたケースである。なお、 本研究は今後の具体的な高温緩和策の検討につながる前段階的研究 としての位置づけもあり、各条件設定において最大の効果（もしく は極端な効果）を把握しておくことが必要と考えた。

Case 1 は多治見自体の都市化の影響を検討するケースで、多治見 市域（10 km×10 km、図 3 の実線枠内）において土地利用データが 「都市」の領域の約半分を「草原」に置き換えたものである（計 27 メッシュの「都市」のうち 13 メッシュを「草原」に変更。「都市」 メッシュと「草原」メッシュは交互に配置) 注3)。Case 2 は名古屋の 都市化の影響を検討するケースで、名古屋市域 $(25 \mathrm{~km} \times 25 \mathrm{~km}$ 、図 3 の点線枠内）において土地利用データが「都市」の領域を全て「草 
原」に置き換えたものである。Case 3 は多治見の西部に位置する琵 琶湖からの湖風の影響を検討寸るため、琵琶湖の土地利用データを 「水域」から全て「草原」に置き換えたものである。常松ら ${ }^{12)}$ は気 象モデル RAMS（Regional Atmospheric Modeling System）による検討 を通じて、琵琶湖からの湖風が夏季晴天日 ・日中の名古屋（名古屋 市北部〜北東部）の風系に及ぼす影響を指摘しているが、多治見へ のその間接的な影響の有無も含めて検討する。ただし、第 3 領域で は琵琶湖全体は含まれないため（わずかに一部が存在）、主に第 2 領域でその土地利用データを変更している。

\section{5 解析条件}

全てのケースにおいて、初期值と境界值には NCEP（National Centers for Environmental Prediction) Final Analysis データ（解像度 $1^{\circ}$ $\times 1 \circ 、 6$ 時間毎）を用いた。土地利用データは平成 18 年国土数值情 報土地利用 3 次メッシュデータ（格子間隔 $100 \mathrm{~m} ｛ }^{13)}$ を利用した。 ただし本研究では、国土数值情報のメッシュデータで 11 区分されて いる土地利用データをUSGS（United States Geological Survey）で用 いられている、(1)都市、(2)湿った農耕地と放牧地、(3)農耕地と草原、 (4)草原、(5)混合林、(6)水域の 6 区分に再分配している。表 4 はそれ ぞれの土地利用に与えた地表面パラメータである。乱流モデルは Mellor-Yamada-Janjic モデル ${ }^{14), 15)}$ を適用した。地表面モデルは Noah-LSM を用い、土地利用が「都市」区分域（図 3 の灰色部分） には Kusaka らの都市キャノピーモデル ${ }^{16)}$ を導入した。表 5 は本研 究で用いた都市キャノピーモデル内のパラメータ值で、これらは名 古屋市の GIS データを基に設定した。建物平均高さと建ぺい率は平 成 18 年建物用途別現況調查データ、緑被率は平成 17 年緑被率調查 データから、名古屋市全域の平均值としてそれぞれ算出した。表 5 に示寸都市キャノピーモデルのパラメータ值は第 3 領域の「都市」 区分域（図 3 参照）で全て同じとしているが、これらは本来、都市 によって変化する值である。しかし、今回対象とした多治見市を始 めとして、パラメータ設定のためのデータ (GIS データ) が十分に 整備されていない地域も多く、設定が困難であったため、本研究で は全ての「都市」区分域において上述の名古屋市のデータから得ら れたパラメータ值を代用した。それぞれの都市の規模に応じたパラ メータ值の設定は今後の課題としたい。表 6 は WRF 内で使用した 主な物理モデルである。離散化手法は、移流項の空間差分スキーム には水平方向に 5 次精度風上差分、鉛直方向に 3 次精度風上差分、 拡散項には 2 次精度中心差分を用いた。時間差分スキームは 3 次精 度 Runge-Kutta 法を使用した。CFL 条件を考慮して時間差分間隔は、 第 1 領域で 100 秒、第 2 領域で 20 秒、第 3 領域で 4 秒（音波関連項 はタイムスプリッティングにより 1 秒の時間刻みで計算）とした。

\section{3. 結果と考察}

\section{1 現状再現解析（Case 0) と予測精度の検証}

本研究で用いた WRF の予測精度を検証するため、まず観測デー 夕との比較を行う。図 4 (a)〜 (e)は 2006 年〜2010 年それぞれの 8 月 における多治見の気温の日変化について、アメダス観測データ（地 上 $1.5 \mathrm{~m}$ ） と現状再現を目的とした Case 0 の結果（地上 $2 \mathrm{~m} ）$ を比 較したものである。なお、ここで示す気温は時刻別に 8 月 1 ケ月分 を平均したものである。2008 年では、1 日を通じて観測と Case 0 が 良く対応した結果となっている。2009 年と 2010 年では、Case 0 の
表 4 各種土地利用区分の地表面パラメータ

\begin{tabular}{|l|c|c|c|c|c|}
\hline \multicolumn{1}{|c|}{ 土地利用 } & $\begin{array}{c}\text { アルベド } \\
{[-]}\end{array}$ & $\begin{array}{c}\text { 蒸発効率 } \\
{[-]}\end{array}$ & $\begin{array}{c}\text { 放射率 } \\
{[-]}\end{array}$ & $\begin{array}{c}\text { 粗度長 } \\
{[\mathrm{m}]}\end{array}$ & $\begin{array}{c}\text { 熱慣性 } \\
{\left[\mathrm{call}^{2} / \mathrm{cm}^{2} \mathrm{Ks}^{1 / 2}\right]}\end{array}$ \\
\hline \hline (1) 都市 & \multicolumn{5}{|c|}{ 都キャノピーモデル ${ }^{16)}$ を導入 } \\
\hline $\begin{array}{l}\text { (2) 湿った農耕地と } \\
\text { 放牧地 }\end{array}$ & 0.18 & 0.50 & 0.985 & 0.10 & 0.04 \\
\hline (3) 農耕地と草原 & 0.18 & 0.25 & 0.980 & 0.14 & 0.04 \\
\hline (4) 草原 & 0.19 & 0.15 & 0.960 & 0.12 & 0.03 \\
\hline (5) 混合林 & 0.13 & 0.30 & 0.970 & 0.50 & 0.04 \\
\hline (6) 水域 & 0.08 & 1.00 & 0.980 & 0.0001 & 0.06 \\
\hline
\end{tabular}

表 5 都市キャノピーモデルのパラメータ

\begin{tabular}{|l|c|l|c|}
\hline (1) 建物平均高さ [m] & 7.0 & (4) 緑被率 [-] & 0.25 \\
\hline (2) 天空率 [-] & 0.69 & (5) 日最大人工排熱 [W/m $\left.{ }^{2}\right]$ & 50 \\
\cline { 1 - 3 } (3) 建ペい率 [-] & 0.23 & \multicolumn{2}{|l}{} \\
\cline { 1 - 3 }
\end{tabular}

表 6 WRF 内で使用した各種物理モデル

\begin{tabular}{|l|l|}
\hline \multicolumn{1}{|c|}{ 物理過程 } & \multicolumn{1}{c|}{ 使用モデル (スキーム) } \\
\hline \hline (1) 雲物理 & WRF Single-Moment 3-class スキーム \\
\hline (2) 積雲パラメタリゼーション & Kain-Fritsch スキーム (第1 領域のみ) \\
\hline (3) 地表面 & Noah-LSM + 都市キャノピーモデル ${ }^{16)}$ \\
\hline (4) 大気境界層 & Mellor-Yamada-Janjic モデル \\
\hline (5) 長波放射 & Rapid Radiative Transfer Model スキーム \\
\hline (6) 短波放射 & MM5 (Dudhia) スキーム \\
\hline
\end{tabular}

結果は観測よりも日中の気温をやや低く評価しているが、両者は概 ね良く一致している。一方、2006 年と 2007 年では、深夜や早朝の 気温については Case 0 と観測が良く一致しているものの、Case 0 は 観測された日中の高温を再現できていない。2006 年では観測の日最 高気温 (8月 1 ケ月時刻別平均值としての日最高気温) が $34.5^{\circ} \mathrm{C}(14$ 時）であるのに対し、WRF の日最高気温は $32.2^{\circ} \mathrm{C}$ （14 時）となっ ている。2007 年の日最高気温は観測、WRF それぞれで、 $34.1^{\circ} \mathrm{C}(14$ 時)、 $32.1^{\circ} \mathrm{C}$ (15 時) である。両年ともに WRF は日最高気温を $2^{\circ} \mathrm{C}$ 程度過小評価している。WRF の予測精度の更なる向上は今後の課題 であるが、既往の研究 $\left.\left.\left.{ }^{3)}, 4\right), 5\right), 9\right)$ においても、シミュレーション (気象 モデル）は観測された著しい高温を再現できず、観測結果よりも 2 $\sim 4^{\circ} \mathrm{C}$ 程度過小評価することが報告されている。また、観測データは 周辺環境の変化による影響 (近藤 ${ }^{17)}$ が指摘している日だまり効果) を受けている場合もあり、結果の比較には注意が必要である。日だ まり効果については別途検討を行い始めており ${ }^{18)}$ 、その除去・補正 に関しては今後十分に検討したい。

図 5 は多治見周辺 $60 \mathrm{~km} \times 60 \mathrm{~km}$ の範囲における 2006 年と 2007 年の 14 時の 8 月 1 ケ月平均気温分布である(それぞれ 8 月 1 ケ月間 の 14 時の結果を全て平均)。2006 年と 2007 年の WRF の結果は多治 見アメダスで観測された最高気温を再現できていないが（図 4 (a) と (b)参照)、多治見市街地（図中印）が周辺に比べて高温となって いる様子は再現されている。

\section{2 多治見高温化要因の感度解析（Case 1 Case 3 の比較)}

\section{(1) 気温の日変化の比較}

図 6 (a)〜 (e)は 2006 年〜2010 年の 5 年間の多治見における気温の 日変化について、Case 1〜Case 3 の結果を比較したものである。図 7 (a)〜 (e)は各年における Case 0 と Case 1～Case 3 それぞれの気温差の 日変化を比較したものである。なお、図 6、図7 で示している気温 


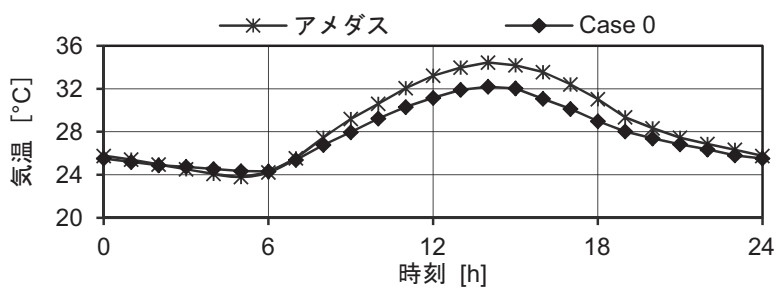

(a) 2006 年

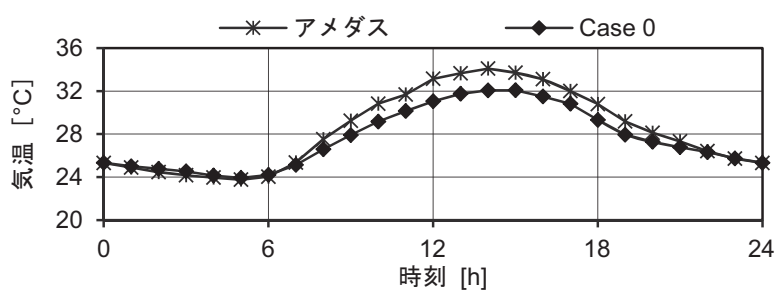

(b) 2007 年

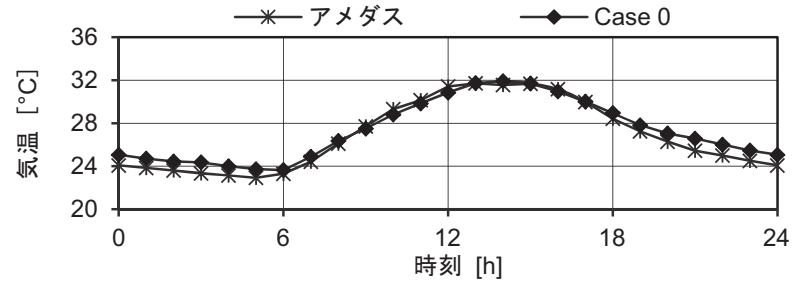

(c) 2008 年

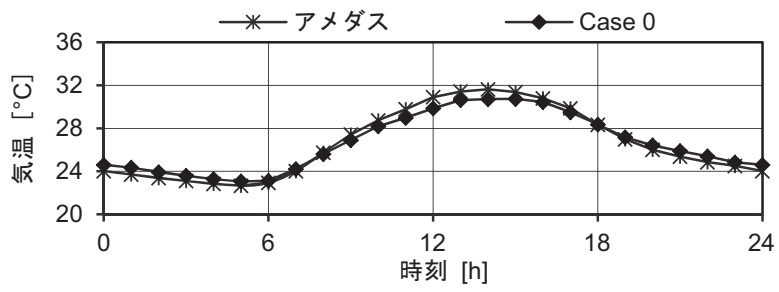

(d) 2009 年

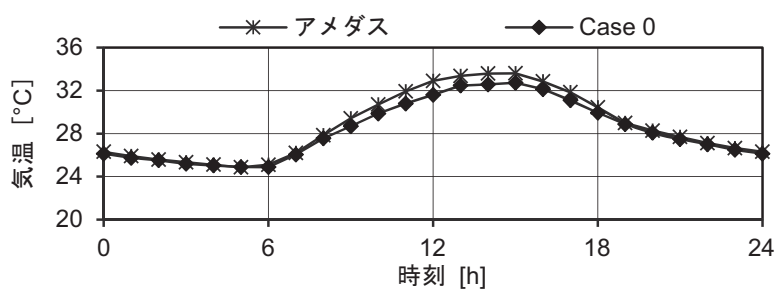

(e) 2010 年

図4 観測とシミュレーションの気温日変化の比較

(8月 1 ケ月時刻別平均值、アメダス : 地上 $1.5 \mathrm{~m} 、 \mathrm{WRF}:$ 地上 $2 \mathrm{~m}$ )

(気温差) は 8 月 1 ケ月の時刻別平均值である。ただし、図 4 の結 果とは異なり（図 4 の Case 0 の結果は多治見アメダス観測点を含む 1 メッシュ地点の結果を表示)、さらに多治見市街地 $2 \mathrm{~km} \times 2 \mathrm{~km}$ (ア メダス観測点を含むメッシュを基点に 4 メッシュ分）の範囲の平均 を施している注4)。

2006 年 2010 年の全ての年において、多治見市域 $(10 \mathrm{~km} \times 10 \mathrm{~km})$ の「都市」区分域の約半分を「草原」に変更した Case 1 の結果が、 1 日を通じて最も大きな気温低下となっている。図 7 (a) (e)を見る と、現状（Case 0）に対する Case 1 の気温低下は年ごとに多少異な っているが、全体的な傾向は全ての年で同様である。すなわち、午

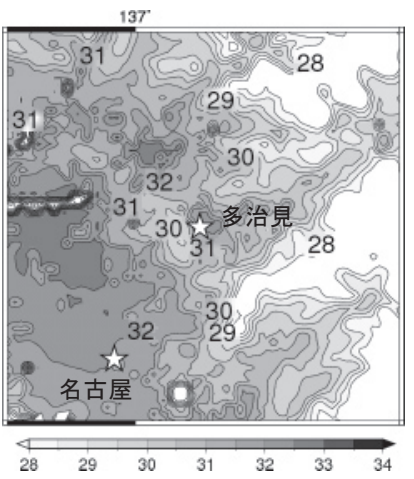

(a) 2006 年

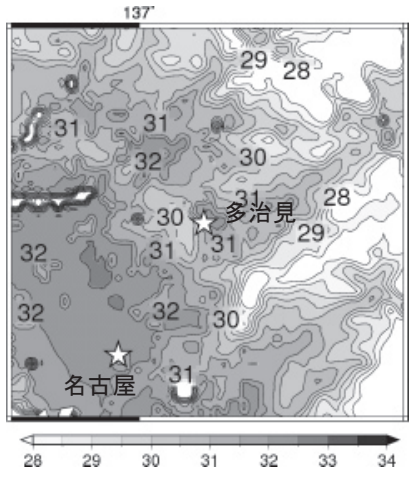

(b) 2007 年
図 514 時における気温分布 (Case $0: 8$ 月 1 ケ月平均值、地上 $2 \mathrm{~m}$ )

前中は気温低下が小さく、夕方から夜間にかけて大きな気温低下 (2006 年と 2010 年は 19 時、2007 年〜2009 年は 18 時に最大の気温 低下）が生じる結果となっている。多治見の都市化の影響が夜間に 大きいこと、寸なわち、ヒートアイランド強度が夜間に大きくなる ことは既往文献例えば 199-22)の知見と整合している。

名古屋市域 $(25 \mathrm{~km} \times 25 \mathrm{~km})$ の「都市」区分域の全てを「草原」 に変更した Case 2 では、各年とも午後に目立った気温低下が生じて いる。各年の Case 0 に対し、2006 年は 15 時に最大となる $0.5^{\circ} \mathrm{C} の$ 気 温低下、2007 年は 17 時、2009 年と 2010 年は 16 時にそれぞれ最大 となる $0.3^{\circ} \mathrm{C}$ 気温低下が生じている。2008 年の気温低下分が一番 少なく、14 時に最大 $0.2^{\circ} \mathrm{C}$ 気温低下である。図 8 は 2006 年におけ る Case 2 と Case 0 の風速差の分布（地上 $10 \mathrm{~m}$ ）である。同図は 2006 年の Case 2 において最大の気温低下となった 15 時を含む 14 時〜 16 時の 8 月 1 ケ月平均值を示している。海風の侵入を阻害する名古屋 市域内の「都市」がなくなることにより、名古屋市域内で南〜南南 西の風が強くなっている様子が見てとれる。その結果、多治見への 海風の侵入度合も強まり、15 時を最大に目立った気温低下が生じた と考えられる。

一方、琵琶湖を全て「草原」に変更した Case 3 は、2007 年以外の 年では、Case 0 に対して最大 $0.2^{\circ} \mathrm{C}$ 程度の気温低下が生じているが 1 日を通じて気温変化は少ない。また、各年において特定の変化傾向 は見られない。2007年は、Case 0 に対して 17 時に $0.3^{\circ} \mathrm{C}$ 気温低下、 15 時に $0.2^{\circ} \mathrm{C}$ の気温上昇、といったように、1 日の変動がやや大き くなっている。ただし、Case 3 の場合、その変更が多治見の気温に 直接影響を及ぼしているというよりも、琵琶湖の位置を中心として 大規模な気象場の変化が生じ、その間接的な影響が多治見の気温変 化に多少及んでいると考えられる(後述の図 10～図 14 の(c)も参照)。

図 9 は、多治見における各ケースの Case 0 との気温差の日变化を 2006 年から 2010 年の 5 年間で平均（図 7 の各ケースの 5 年分の結 果を平均）したものである。上述したように、今回のシミュレーシ ヨンでは 2006 年〜2010 年の多治見高温化に対して、Case 1 の多治 見自体の都市化（ヒートアイランド）の影響が最も大きい結果とな っている。Case 2 の名古屋の都市化（ヒートアイランド）の影響は、 図 7 に示寸ように各年によって最大の気温低下となる時刻は多少異 なっているが、 5 年平均すると 16 時をピークとしてその前後の時間 帯に目立った気温低下が見られている。なお、Case 3 の琵琶湖から 


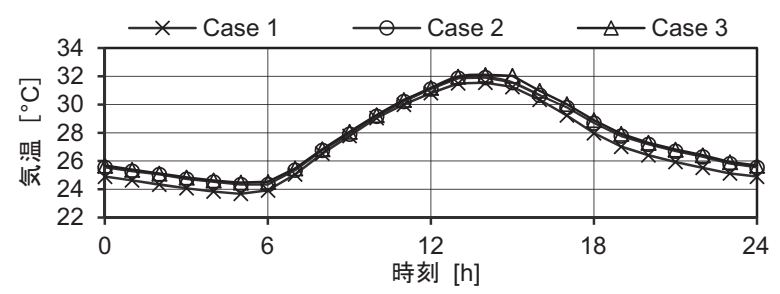

(a) 2006 年

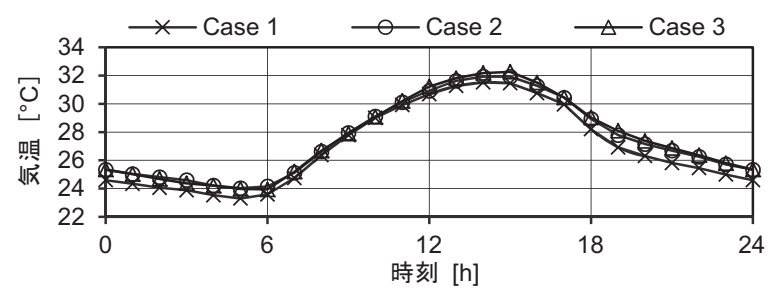

(b) 2007 年

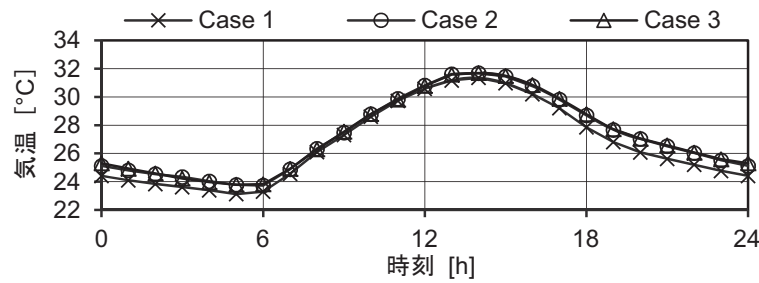

(c) 2008 年

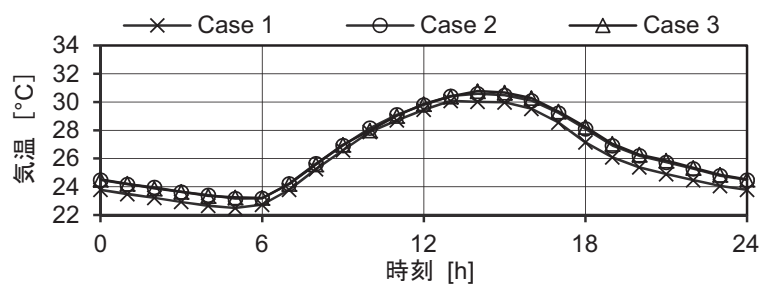

(d) 2009 年

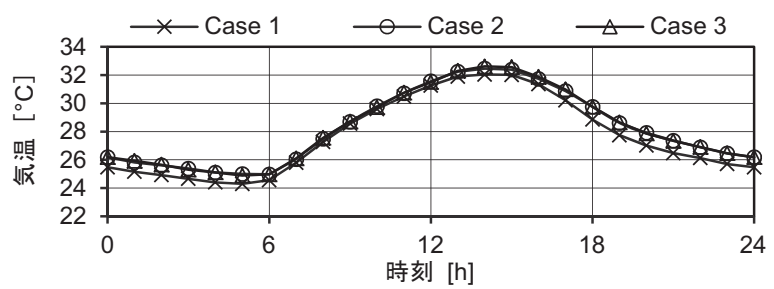

(e) 2010 年

図 6 気温日变化の比較 $(8$ 月 1 ケ月時刻別平均值、地上 $2 \mathrm{~m}$ )

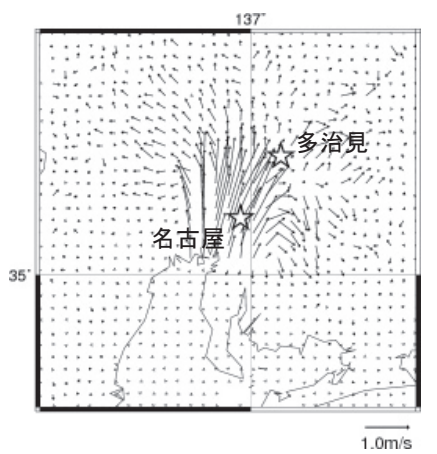

図 8 (Case 2-Case 0) の風速差の分布 (2006 年 8 月 1 ケ月 14 時〜 16 時の平均値、地上 $10 \mathrm{~m}$ )

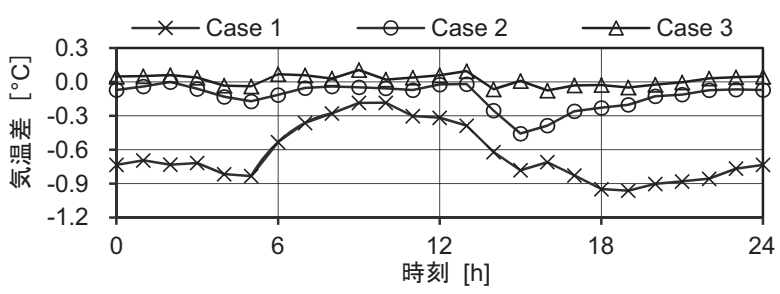

(a) 2006 年

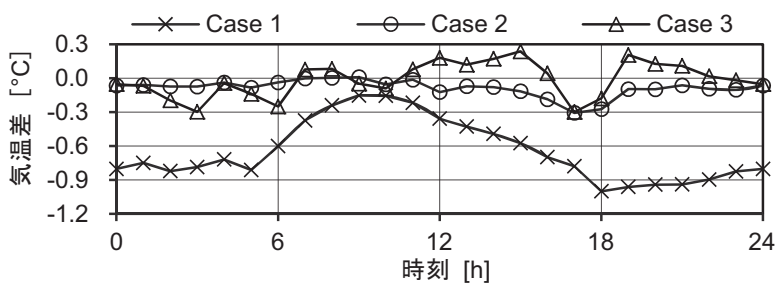

(b) 2007 年

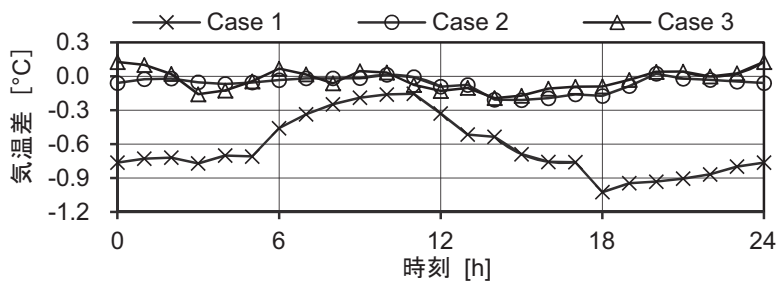

(c) 2008 年

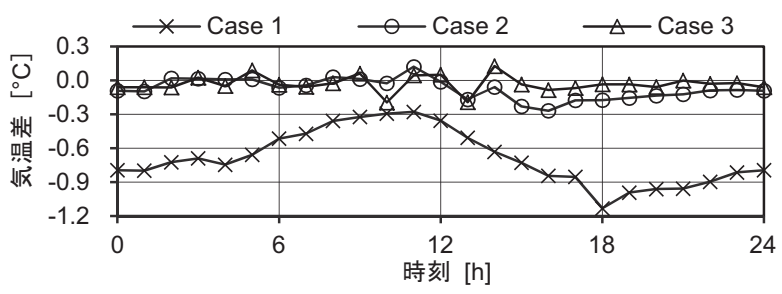

(d) 2009 年

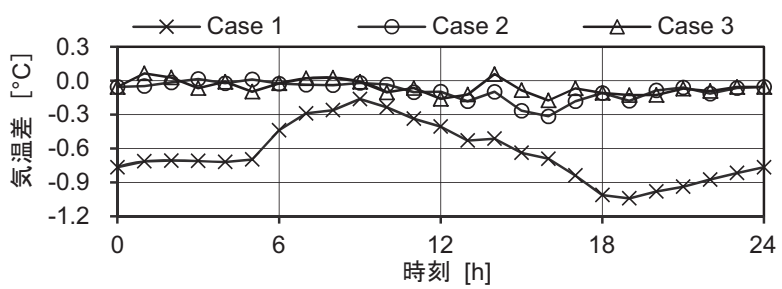

(e) 2010 年

図 7 現状（Case 0) との気温差の日変化の比較 (8月 1 ケ月時刻別平均值、地上 $2 \mathrm{~m}$ )

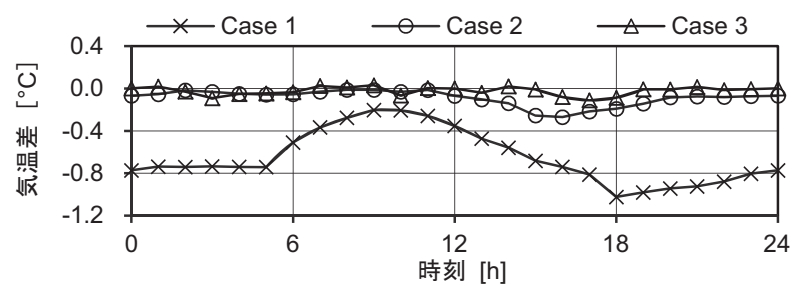

図 9 現状 (Case 0) との気温差の日変化の比較 （2006 年～ 2010 年の 8 月 1 ケ月時刻別平均值、地上 $2 \mathrm{~m}$ ) 
の湖風の多治見への影響は 5 年平均寸るとほとんど見られない。

\section{（2）各種要因の影響範囲の比較}

Case 1〜Case 3 の条件変更が及ぼす影響範囲を見るため、第 3 領 域全体（図 2 参照）の気温分布（地上 $2 \mathrm{~m}$ ）を比較する。図 10 (a) 〜 (c)は2006年の各ケースにおける Case 0 との気温差の分布である。 なお、ここに示寸気温差は日中午後 6 時間（13 時〜18 時）の気温を 8 月 1 ケ月分全て平均したものである。同様に、図 11〜図 14 はそれ ぞれ 2007 年〜2010 年の結果を示したものである。いずれの年でも、 Case 1 の変更（多治見市域の「都市」区分域の約半分を「草原」に 変更）で大きな気温低下が生じる範囲はほぼ多治見市域内に限られ ている。Case 2 の変更 (名古屋市域の「都市」区分域を全て「草原」 に変更）の影響は名古屋市域内外の広範囲に及び、名古屋市域外で は各年ともに名古屋の北部〜東部方面に大きく気温低下寸る領域が 生じている。Case 3（琵琶湖を全て「草原」に変更）では、各年と もに滋賀県や三重県北部（図の左端）に広く気温上昇する領域が見 られ、琵琶湖からの湖風が泠却効果を持つことを示している。 2.4 節で述べたように、常松ら $\left.{ }^{12}\right)$ は琵琶湖からの湖風の名古屋の風系へ の影響を指摘しているが、図 10〜図 14 の(c)の結果を見る限り、琵 琶湖の湖風が名古屋の気温に及ぼす影響はほとんど見られてない。 また、多治見の気温変化に対しての寄与もほとんどない。

\section{4. まとめ}

本研究では、領域気象モデル WRF を用いて岐阜県多治見市の高 温化形成要因の感度解析を行った。2006 年〜2010 年の 5 年間それぞ れの 8 月 1 ケ月間を対象として、(1)多治見自体の都市化（ヒートア イランド)、(2)名古屋の都市化（ヒートアイランド)、(3)琵琶湖から の湖風の影響、の各々が多治見の気温に及ぼす影響を検討した。

(1) 今回設定した条件では、多治見高温化に対して、いずれの年に おいても多治見自体の都市化（ヒートアイランド）の影響が最 も大きいことが示された。ただし、多治見の都市化が気温変化 に及ぼす影響範囲はほぼ多治見市域内に限られていた。多治見 高温化に対して多治見自体のヒートアイランドの影響が大きい ことは、最近行われた多治見およびその周辺都市における夏季 の集中観測結果 ${ }^{23)}$ からも確認されてきている。

(2) 名古屋の都市化（ヒートアイランド）も多治見高温化に少なか らず影響を及ぼすことが確認された。名古屋の都市化が及ぼす 影響は午後（特に 14 時〜 17 時）に顕著となった。名古屋の「都 市」の存在により多治見への海風の侵入が弱まることが、多治 見の気温上昇の理由の 1 つとして考えられた。

(3) 琵琶湖からの湖風は比較的広い範囲で泠却効果をもたらすもの の、多治見の気温変化に対する寄与はほとんど見られなかった。

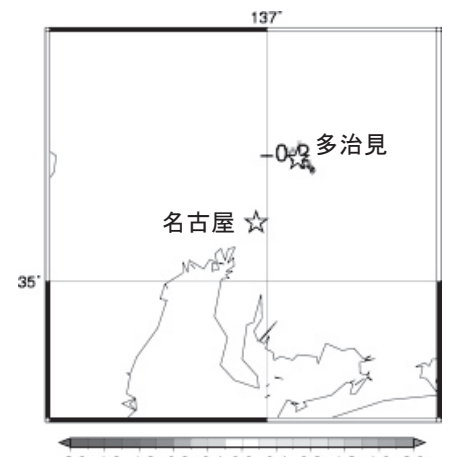

(a) Case 1-Case 0

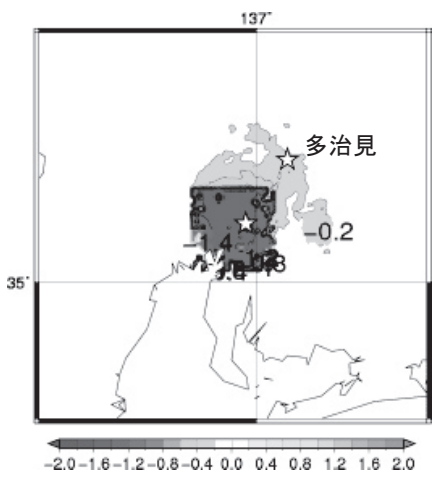

(b) Case $2-$ Case 0

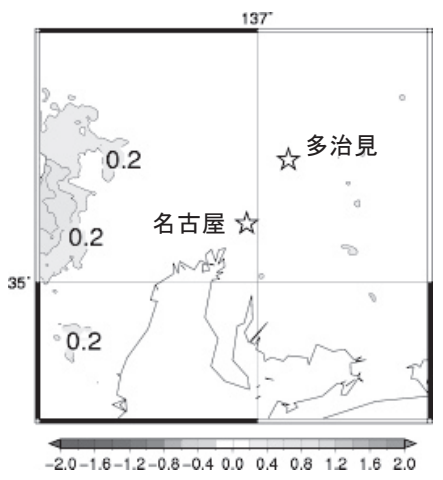

(c) Case 3-Case 0

図 10 Case 0 との日中午後平均気温差の分布（2006 年 8 月 1 ケ月 13 時〜 18 時の平均值、地上 $2 \mathrm{~m}$ )

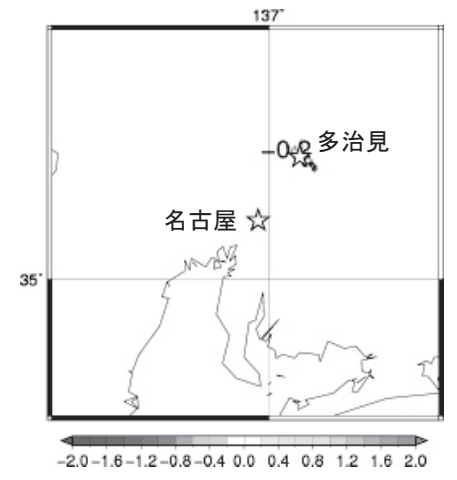

(a) Case 1-Case 0

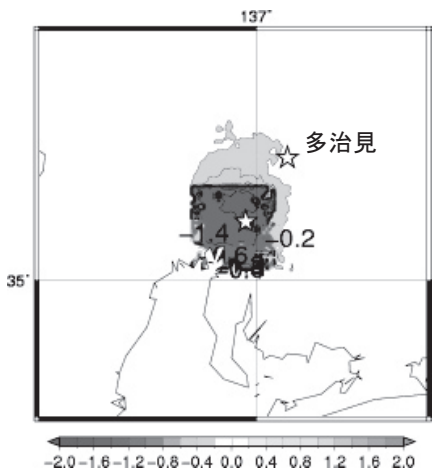

(b) Case 2-Case 0

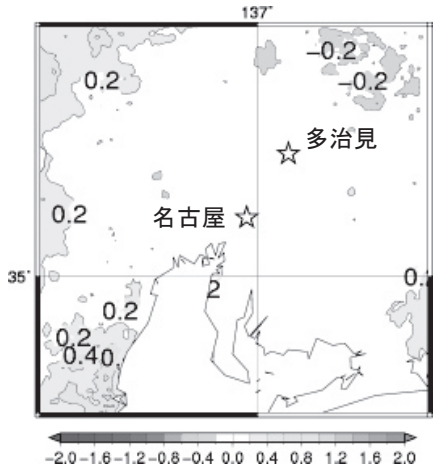

(c) Case 3-Case 0

図 11 Case 0 との日中午後平均気温差の分布 $(2007$ 年 8 月 1 ケ月 13 時 18 時の平均值、地上 $2 \mathrm{~m})$ 


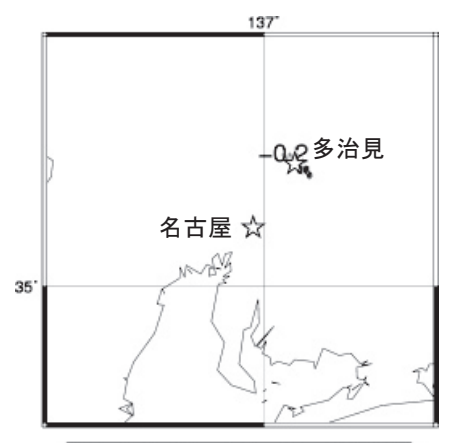

$\begin{array}{llllllll}\longrightarrow 2.0-1.6-1.2-0.8-0.4 & 0.0 & 0.4 & 0.8 & 1.2 & 1.6 & 2.0\end{array}$

(a) Case 1-Case 0

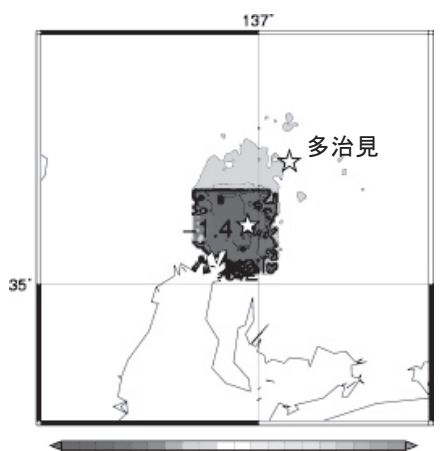

$\begin{array}{llllllll}2.0-1.6-1.2-0.8-0.4 & 0.0 & 0.4 & 0.8 & 1.2 & 1.6 & 2.0\end{array}$

(b) Case 2-Case 0

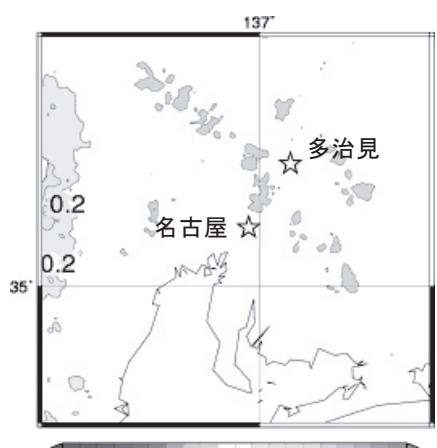

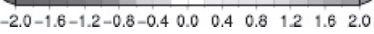

(c) Case 3-Case 0

図 12 Case 0 との日中午後平均気温差の分布（2008 年 8 月 1 ケ月 13 時〜 18 時の平均值、地上 $2 \mathrm{~m}$ )

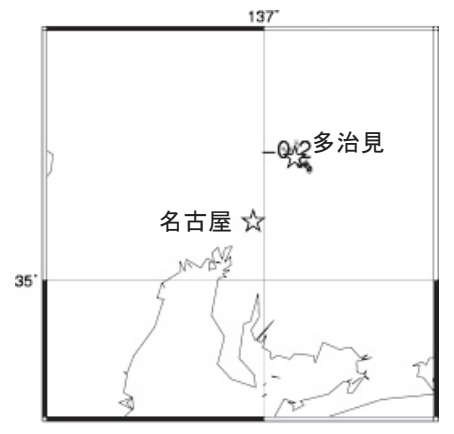

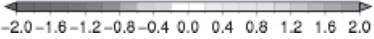

(a) Case 1-Case 0

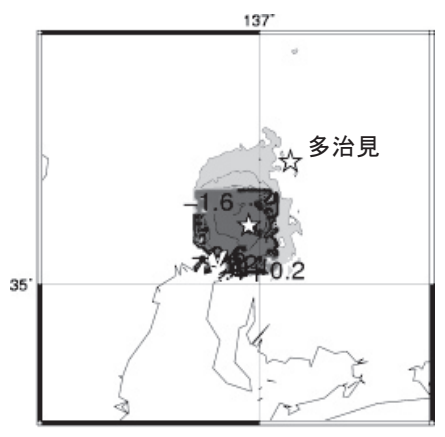

\begin{tabular}{lllllllll}
\hline$-2.0-1.6-1.2-0.8-0.4$ & 0.0 & 0.4 & 0.8 & 1.2 & 1.6 & 2.0
\end{tabular}

(b) Case 2-Case 0

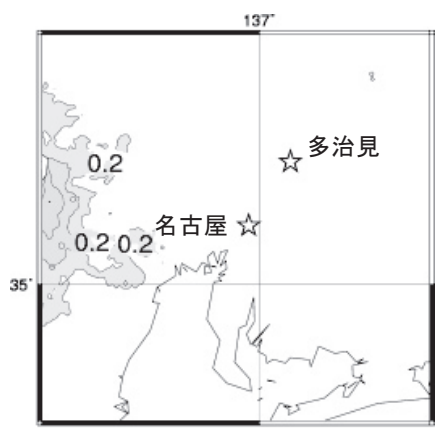

\begin{tabular}{lllllll}
\hline$-2.0-1.6-1.2-0.8-0.4$ & 0.0 & 0.4 & 0.8 & 1.2 & 1.6 & 2.0
\end{tabular}

(c) Case 3-Case 0

図 13 Case 0 との日中午後平均気温差の分布（2009 年 8 月 1 ケ月 13 時〜 18 時の平均值、地上 $2 \mathrm{~m}$ )

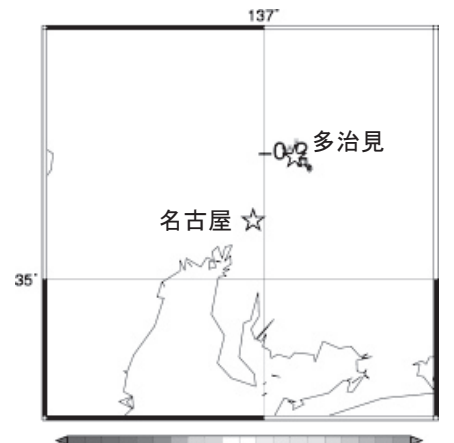

$-2.0-1.6-1.2-0.8-0.4 \quad 0.0 \quad 0.4 \quad 0.8 \quad 1.2 \quad 1.62 .0$

(a) Case 1 - Case 0

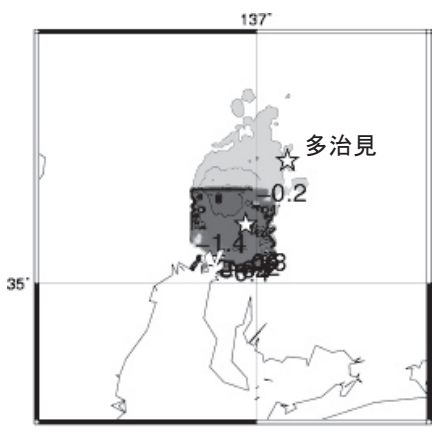

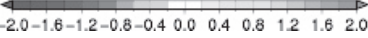

(b) Case $2-$ Case 0

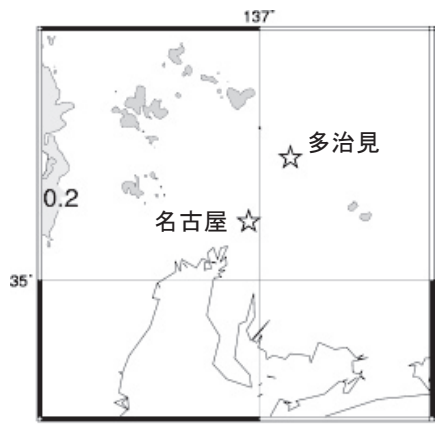

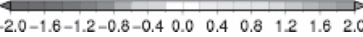

(c) Case 3 - Case 0

図 14 Case 0 との日中午後平均気温差の分布（2010 年 8 月 1 个月 13 時〜 18 時の平均值、地上 $2 \mathrm{~m})$

\section{謝辞}

本研究は文部科学省「気候変動適応研究推進プログラム (RECCA)」 の 1 研究課題（研究代表者：飯塚悟）の一環として行ったものであ る。ここに記して謝意を表す。

注

注 1) 短期解析の一例として、2006 年 8 月 18 日および 8 月 26 日の多治見に おける現状（Case 0) と各検討ケース（Case 1〜Case 3: 検討ケースに ついては 2.4 節参照）の気温差の日変化を図 15 に示す。同図に示され るように、短期解析の場合、選択した日によって各ケースの気温差 (各 ケースの影響度合）は異なっている。したがって、統計的に有意な差
を検討するためには、ある程度長期間の解析が必要となる。

注 2) 多治見高温化に対寸る周辺地理状況の影響の検討として、多治見周辺 の山岳の標高が $200 \mathrm{~m}$ 以上の領域を多治見市街地の平均標高である $200 \mathrm{~m}$ に変更したケース（盆地効果の影響の検討を意図したケース。以 下、便宜上「Case 4」と表記）の解析も実施したが、十分な結果は得ら れなかった。図 16 に結果の一例として、多治見周辺 $60 \mathrm{~km} \times 60 \mathrm{~km} の$ 領域における 2006 年 8 月の 14 時(2006 年 8 月 1 ケ月の 14 時の平均值) の Case 4 と Case 0 の気温差の分布 (同図(a)) と、同時刻の Case 4 と Case 0 の風速差（鉛直成分）の分布（同図(b)）を示す。同図(a)に示さ れるように、標高を低くした部分（実線枠内）では高低差の影響で気 温が上昇しているが、大気の断熱減率 $\left(0.006 \sim 0.01^{\circ} \mathrm{C} / \mathrm{m}\right.$ 程度) に対応 する気温上昇には至っていない部分も多い。また、同図(b)の風速差の 分布を見ると、標高を低くした部分の周囲（外側）で顕著な上昇流が 


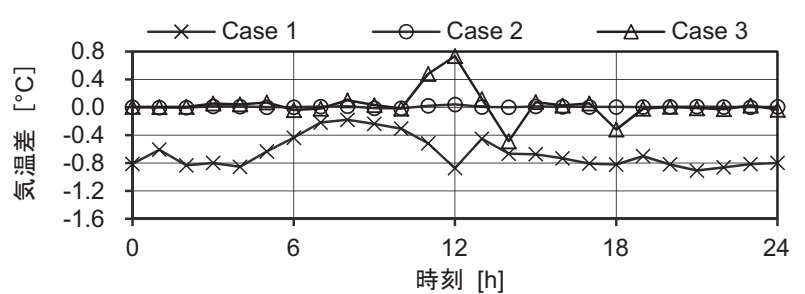

(a) 2006 年 8 月 18 日

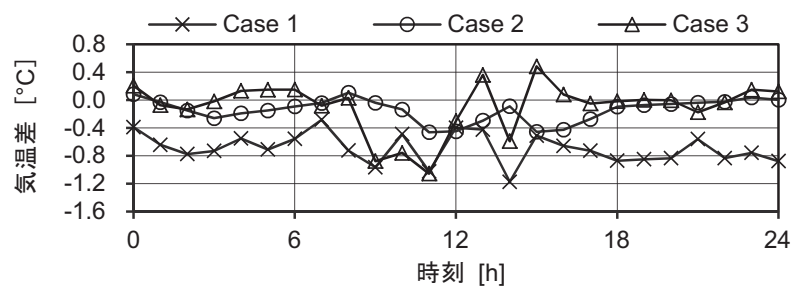

(b) 2006 年 8 月 26 日

図 15 現状（Case 0）との気温差の日変化の比較（地上 $2 \mathrm{~m} ）$

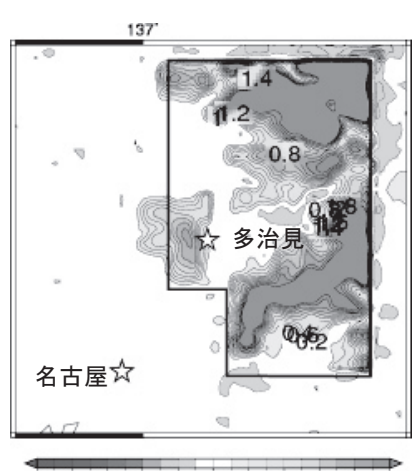

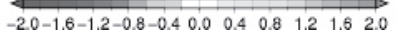

(a) 気温差 (地上 $2 \mathrm{~m}$ )

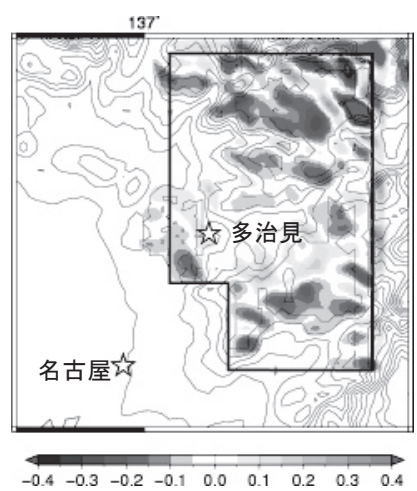

(b) 風速差

(鉛直成分、地上約 $30 \mathrm{~m}$ )
図 16 (Case 4-Case 0) の気温差と風速差の分布 $(2006$ 年 8 月 1 ケ月の 14 時の平均值)

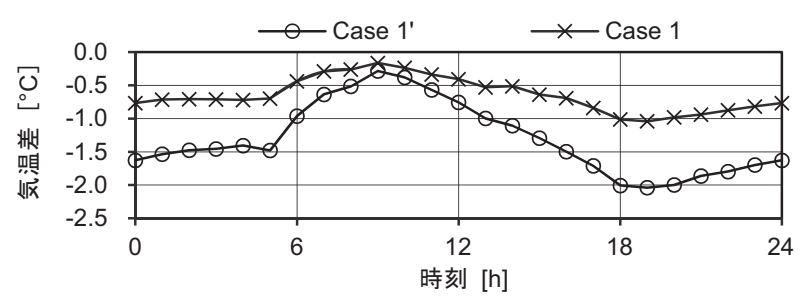

図 17 現状（Case 0) との気温差の日変化の比較

(2010 年 8 月 1 ケ月時刻別平均值、地上 $2 \mathrm{~m}$ )

生じ、別の新たな地形影響が現れてしまっている。多治見高温化に対 寸る盆地効果の影響については、今後再検討が必要である。

注 3) Case 1 で行う多治見市域の「都市」区分域から「草原」への変更に関 しては、事前に「都市」区分域を全て「草原」に変更する予備ケース （Case 1'）の検討も行った。多治見における現状（Case 0) との気温差 の日変化について、Case 1 と Case 1'の結果を図 17 に示す（結果は図 7 と同様に算出)。Case 1'の場合、Case 0 に対する気温低下は最大 $2.0^{\circ} \mathrm{C}$ (19 時) となっている。「都市」の緩和割合は要検討事項であるが、 Case 1'のような気温低下は他の検討ケースに比べて極端に大きく、他 のケースの影響度合が把握し難くなると考え、Case 1 の条件設定を採 用した。一方、多治見から離れた条件を検討する Case 2 (名古屋市域
の「都市」区分域を「草原」に変更）やCase 3（琵琶湖の「水域」を 「草原」に変更）については、最大の効果を把握しておくことが必要 と考え、対象領域全体を変更することとした。

注 4) Case 1 では多治見市域で「都市」と「草原」の条件を半分ずつ与えて いるが (2.4 節参照)、隣接する「都市」メッシュと「草原」メッシュ に执いても両者の結果に大きな差が生じていた。そのため、両者の割 合 (影響) が半分ずつになるように 4 メッシュ分 $(2 \mathrm{~km} \times 2 \mathrm{~km}$ の範囲 $)$ の平均を取ることとした。これに伴い、他のケースの結果も同じ位置 での 4 メッシュ平均值を用いている。

\section{参考文献}

1) 気象庁: 気象統計情報, http://www.jma.go.jp/jma/menu/report.html, 2011.1.10 参照.

2) 藤部文昭：日本における近年の著しい夏季高温の発生状況，地理学評論， 77(3), pp.119-132, 2004.3.

3) 渡来靖, 中川清隆, 福岡義隆 : 領域気象モデルを用いた関東平野中央部に おける 2007 年 8 月 15-16 日の猛暑の数值シミュレーション, 日本生気象 学会雑誌, 46(1), pp.35-41, 2009.3.

4) 篠原善行, 眞下国寬, 桜井美菜子, 須永次雄: 関東地方で日最高気温が $40^{\circ} \mathrm{C}$ を越えた 2007 年夏の高温その 2 JMANHM による日最高気温の 再現実験と高温要因の考察〜, 天気, 56(7), pp.51-56, 2009.7.

5) Takane, Y., Kusaka, H. : Formation mechanisms of the extreme high surface air temperature of $40.9^{\circ} \mathrm{C}$ observed in the Tokyo metropolitan area: Considerations of dynamic foehn and foehnlike wind, Journal of Applied Meteorology and Climatology, 50, pp.1827-1841, 2011.9

6) Skamarock, W. C., Klemp, J. B., Dudhia, J., Gill, D. O., Barker, D. M., Duda, M. G., Huang, X. Y., Wang, W., Powers, J. G. : A description of the Advanced Research WRF version 3, NCAR/TN-475+STR, NCAR Technical Note, 2008.6.

7) WRF USERS PAGE : http://www.mmm.ucar.edu/wrf/users/, 2011.1.10 参照.

8）日下博幸: 領域気象モデル WRF について, ながれ, 28(1), pp.3-12, 2009.2.

9) 小出雅之, 瀧本秀一郎, 稲垣広已, 則竹俊樹 : 多治見で最高気温が $40.9^{\circ} \mathrm{C}$ を記録した日のJMANHM による気温分布の再現実験, 平成 20 年度東京 管区調查研究会誌, 41, 2008

10）飯塚悟, 金原和矢, 日下博幸, 原政之, 秋本祐子：領域気象モデル WRF による名古屋都市圈の温熱環境シミュレーション（その 1) 夏季の名古 屋の温熱環境を対象とした現状再現の精度検証と疑似温暖化手法を併用 した将来予測の試み, 日本建築学会環境系論文集, 75, 647, pp.87-93, 2010.1 .

11）飯塚悟, 金原和矢, 日下博幸, 原政之 : 領域気象モデル WRF による名古 屋都市圈の温熱噮境シミュレーション（その 2) 2070 年代夏季温熱環境 の長期トレンド予測, 日本建築学会環境系論文集, 76, 662, pp.425-430, 2011.4 .

12）常松展充, 甲斐憲次: 夏季晴天日の濃尾平野における地上風収束域の污 染質と雲分布, 天気, 50(7), pp.527-537, 2003.7.

13）国土交通省計画局：国土数值情報ダウンロードサービス, http://nlftp.mlit. go.jp/ksj/, 2011.1.10 参照.

14) Janjic, Z. I. : The step-mountain coordinate: physical package, Monthly Weather Review, 118, pp.1429-1443, 1990.6

15) Janjic, Z. I. : Nonsingular implementation of the Mellor-Yamada level 2.5 scheme in the NCEP meso model, NCEP Office Note, No. 437, 2002.

16) Kusaka, H., Kondo, H., Kikegawa, Y., Kimura, F. : A simple single-layer urban canopy model for atmospheric models: Comparison with multi-layer and slab models, Boundary-Layer Meteorology, 101, pp.329-358, 2001.12.

17) 近藤純正：近藤純正ホームページ「気温の日だまり効果の補正(1), (2)」, http://www.asahi-net.or.jp/ rk7j-kndu/kenkyu/kenkyu00.html, 2012.6.19 参照.

18）高橋佑輔, 飯塚悟, Ndione Jacques, 吉田伸治：LES による建物周辺の日だ まり効果の推定, 日本流体力学会年会 2011,3D11,3pp, 2011.9.

19) 近藤純正: 水環境の気象学一地表面の水収支・熱収支一, 朝倉書店, 1994 .

20) 藤部文昭: 都市のヒートアイランド, 天気, 54(1), pp.9-12, 2007.1.

21）独立行政法人国立環境研究所地球環境研究センター: ココが知りたい温 暖化「暑い日が増えたのはヒートアイランドが原因?」, http://www.cger. nies.go.jp/ja/library/qa /27/27-2/qa_27-2-j.html, 2011.10.9 参照. 
22) 原政之, 日下博幸, 木村富士男, 若月泰孝: 気象変動が首都圈の都市ヒ一 トアイランドに及ぼす影響一冬季を対象として一, ながれ，29(5), pp.353-361, 2010.10
23) 阿部紫織, 日下博幸, 高木美彩, 岡田牧, 高根雄也, 冨士友紀乃, 永井 徹: 多治見市における夏季の気温分布の実態調查（その 1) , 日本気象学 会 2011 年度春季大会講演予稿集, p.347, 2011.5.

（2011年10月 10 日原稿受理，2012年 7 月 2 日採用決定） 